\title{
Harina de cáscara de vaina de cacao: Una opción para el aprovechamiento de residuos agroindustriales
}

\author{
Cocoa pod hull flour: An option for the use of agroindustrial waste \\ Fernanda Ríos-Pérez ${ }^{a}$, Sergio Soto-Simental ${ }^{a}$, Aurora Quintero-Lira ${ }^{a}$, Javier Piloni-Martini $^{a}$, \\ Norma Güemes-Vera ${ }^{a}$
}

\begin{abstract}
:
The growing concern about the use of agroindustrial waste has generated the search for processes of transformation and reuse of these. Which are little exploited, because their chemical composition and possible transformations are unknown. In the cocoa industry, the cocoa pod shell is discarded in the crops, where it decomposes, spreading the Phytophora spp. Fungus that contaminates the healthy plantation, causing losses to the producers, as well as environmental problems. Therefore, the following research study aims to determine the morphometric characteristics, the proximal chemical analysis and the antioxidant capacity in the cocoa pod shell meal, to evaluate its viability as a raw material. Determining performance, proximal chemical analysis, phenols and antioxidant capacity. Obtaining a percentage of yield of $29 \%$, morphologically reaches a maximum height of $36 \mathrm{~nm}$. The proximal chemical analysis showed a crude fiber percentage of $26.75 \%$, ash $8.41 \%$, humidity $6.26 \%$, protein $5.27 \%$ and fat $0.69 \%$. Reporting a content of phenolic compounds of $8,48 \mathrm{mg}$ of gallic acid / $\mathrm{g}$ dry sample, concluding that cocoa pod husk flour provides ashes and fiber, as well as showing antioxidant capacity, which makes it a raw material with agroindustrial interest.
\end{abstract}

Keywords:

agroindustrial waste, cocoa pod shell meal and antioxidant capacity

Resumen:

La creciente preocupación por el uso de desechos agroindustriales ha generado la búsqueda de procesos de transformación y reutilización de estos. Los cuales son poco explotados, debido a que se desconocen su composición química y posibles transformaciones. En la industria del cacao, la cáscara de vaina de cacao es desechada en los cultivos, donde se descompone, propagando el hongo Phytophora spp que contamina la plantación sana, causando pérdidas a los productores, así como problemas ambientales. Por lo que el siguiente estudio de investigación tiene como objetivo determinar las características morfométricas, el análisis químico proximal y la capacidad antioxidante en la harina de cáscara de la vaina de cacao, para evaluar su viabilidad como materia prima. Determinando el rendimiento, análisis químico proximal, fenoles. Obteniendo un porcentaje de rendimiento del $29 \%$, morfologicamente alcanza una altura máxima de $36 \mathrm{~nm}$. El análisis químico proximal mostró un porcentaje de fibra cruda de $26.75 \%$, ceniza $8.41 \%$, humedad $6.26 \%$, proteína $5.27 \%$ y grasa $0.69 \%$. Reportando un contenido de compuestos fenólicos de $8,48 \mathrm{mg}$ de ácido gálico / g muestra seca. Concluyendo que la harina de cáscara de vaina de cacao, aporta cenizas y fibra, además de mostrar capacidad antioxidante, lo que la convierte en una materia prima con interés agroindustrial.

\section{Palabras Clave:}

desecho agroindustrial, harina de cáscara de vaina de cacao y capacidad antioxidante

\footnotetext{
${ }^{a}$ Autor de Correspondencia, Universidad Autónoma del Estado de Hidalgo, Instituto de Ciencias Agropecuarias,
} 


\section{INTRODUCTION}

Worldwide, there is growing concern about the use of agroindustrial waste due to the threat of reduced sources of food, disappearance of raw materials and the growing world population, which has taken great force in the search for transformation processes, preservation and reuse of biological materials that are treated as waste. The main agro-industrial wastes include husks, barks and seeds of certain fruits, which contain bioactive compounds, which are currently scarcely exploited, because their chemical composition and possible transformations are still unknown [1] and in some cases, these are found in greater amount in the waste, considered waste, than in the own edible or exploited fraction of the fruit in the food industry. In the cocoa industry the main raw material is dried and fermented cocoa beans, when these are processed, three types of co-products are obtained: cocoa pod husk, grain husk and mucilage, which are usually thrown into the plantation of cocoa, where they decompose, spreading the Phytophora spp fungus that contaminates the healthy plantation, causing crop losses and therefore economic decline to cocoa producers [2], as well as environmental problems in the production of greenhouse gases, odors and spread of diseases [1]. In 2013, 3,455,622 metric tons of cocoa shells were produced, estimating an annual growth rate of $3.1 \%$ from 2014 to 2019 [3], which constitute a serious problem of environmental contamination [1]. In this context, the exploitation of cocoa byproducts would expand the diversity of products that could be produced from a single fruit, implying a greater economic benefit to producers and the reduction or complete elimination of waste, impacting positively on the environment [4].

Currently there are few studies worldwide that propose the use of cocoa pod shells. Therefore, it is necessary to carry out an investigation to determine if the elaboration of a flour from the cocoa shells is a by-product that can be used in the food industry. So, the following research study aims to determine morphometric characteristics, proximal chemical analysis and antioxidant capacity in cocoa pod shell meal, to assess its viability as a raw material.

\section{MATERIALS AND METHODS PREPARATION OF FLOUR}

The cocoa pod skin was acquired in the Gregorio Méndez ranchería, in the municipality of Jalpa de Méndez, in the state of Tabasco, whose coordinates are: latitude: $18^{\circ}$ $.15^{\prime} 12$ ", longitude: $93^{\circ} .15^{\prime} 56^{\prime \prime}$. The cocoa pod skin was washed with potable water and soap, then cut lengthwise to obtain thin leaves, which were dried in a brand oven (LUMISTELL) at $60^{\circ} \mathrm{C}$, for 12 hours, then ground in a brand sprayer (GRINDER HC-2000Y2) and passed through a sieve of flour mesh number 8 double $X$, with a diameter of $203 \mathrm{~mm}$.
The yield of cocoa pod hull flour was expressed as the amount of flour obtained as a function of the amount of fruit used, by the following expression [5].

$$
\% \text { flour yield }=\frac{\text { flour weight }}{\text { shell weight }} \times 100
$$

\section{PROXIMAL CHEMICAL ANALYSIS}

Moisture (925.10), ash (923.03), fat by Soxhlet (920.85), protein by Kjeldahl (951.03) and crude fiber (985.29) were determined; according to the methods reported by A.O.A.C. [7] While carbohydrates were calculated by difference. These analyzes were performed in triplicate.

\section{TOTAL PHENOLS}

The content of total phenols was determined by the FolinCiocalteau colorimetric technique, according to the methodology described by Ondo and Ryu [8]. The results were expressed as $\mathrm{mg}$ of gallic acid per $\mathrm{g}$ of dry matter, making measurements in triplicate.

\section{STATISTICAL ANALYSIS}

The experimental design was completely random. The data collected were analyzed by analysis of variance (ANOVA), considering significant differences at $p<0.05$. When these differences were found, Tukey's mean comparison test was used with the statistical package SPSS 19.0 (SPSS Inc., Chicago, IL).

\section{RESULTS}

\section{FLOUR PERFORMANCE}

Cocoa pod hull flour obtained, presented a yield percentage of $29.08 \%$, this means that out of every $100 \mathrm{~kg}$ of cocoa pod skin, $29 \mathrm{~kg}$ of cocoa pod shell meal are obtained.

\section{PROXIMAL CHEMICAL ANALYSIS}

The results obtained from the proximal chemical analysis are shown in Table 1. The cocoa pod shell meal showed significant differences $(p<0.05)$ in all parameters, with an amount of crude fiber of $(26.75 \%)$, ash (8.41). \%), humédad $(6.26 \%)$, protein $(5.27 \%)$, fat $(0.69 \%)$ and finally the carbohydrate content by difference was (52.61\%).

Table 1. Proximate chemical analysis in cocoa pod shell meal.

\begin{tabular}{lc}
\hline Analysis & $\begin{array}{c}\text { Shell meal } \\
\text { cocoa pod } \\
\%\end{array}$ \\
\hline Moisture & $6.26 \pm 0.12^{\mathrm{d}}$ \\
Ashes & $8.41 \pm 0.06^{\mathrm{c}}$ \\
Fat & $0.69 \pm 0.02^{\dagger}$ \\
Protein & $5.27 \pm 0.06^{\mathrm{e}}$
\end{tabular}




\section{Raw Fiber $\quad 26.75 \pm 0.21^{\mathrm{b}}$ \\ Carbohydrates $\quad 52.61 \pm 0.02^{\mathrm{a}}$}

The values represent the mean and standard deviation, the superscripts ${ }^{a, b, c, d, d, f, f}$ in the same column, represent significant differences $(\mathrm{P}<0.05)$.

\section{TOTAL PHENOLS}

The results are shown in Table 2, showing a significant difference $(P<0.05)$ in the cocoa pod shell meal in the content of phenolic compounds ( $8.48 \mathrm{mg}$ gallic acid / $\mathrm{g}$ dry sample).

Table 2. Content of antioxidants in cocoa pod shell meal.

\begin{tabular}{ll}
\hline \multicolumn{1}{c}{ Analysis } & $\begin{array}{l}\text { Shell meal } \\
\text { cocoa pod }\end{array}$ \\
\hline $\begin{array}{l}\text { Phenols } \\
\text { mg gallic acid / g dry } \\
\text { sample }\end{array}$ & $6.26 \pm 0.12^{\mathrm{b}}$
\end{tabular}

The values represent the mean and standard deviation, the superscripts ${ }^{\mathrm{a}, \mathrm{b}, \mathrm{c}}$ in the same column represent significant differences $(P<0.05)$.

\section{CONCLUSIONS}

In the present work of investigation shows that the flour of husk of pod of cocoa, contributes ashes and fiber, in addition to show antioxidant capacity, which turns it into a raw material with agroindustrial interest.

\section{REFERENCES}

[1] Panak, B.J., Ackar, D., Jokic, S., Jozinovic, A., Babic, J., Milicevic, B., Subaric, D. y Pavlovic, N. (2018). Cocoa Shell: A by-product with great pontential for wide application. Molecules, 23, 1404-1418.

[2] Villamizar, Y.L., Rodríguez, J.S., y León, L.C. (2016). Caracterización fisicoquímica, microbiológica y funcional de harina de cáscara de cacao (Theobroma cacao L.) variedad CCN-51.1. Cuaderno Activa, 1 (9), 65-75. Silva G, Galeano E, Correa J. Compliance with the treatment. Acta Médica Colombiana 2005; 30(4): 268-73.

[3] World Cocoa Foundation. (08 de marzo de 2019). Obtenido de World Cocoa Foundation: https://www.worldcocoafoundation.org/

[4] Leao, D.P., Franca, A.S., Oliveira, L.S., Bastos, R., y Coimbra, M.A. (2017). Physicochemical characterization, antioxidant capacity, total phenolic and proanthocynidin content of flours prepared from pequi (Caryocar brasilense Camb.) fruit by-products. Food Chemistry, 225, 146-153.

[5] García, O., Aiello, C., Peña, M.C., Ruiz, J.L., y Acevedo, I.C. (2012). Caracterización físico-química y propiedades funcionales de la harina obtenida de granos de quinchoncho (Cajanus cajan (L.) Millsp.) sometidos a diferentes procesamientos. Revista Cientifica UDO Agrícola, 12 (4), 918-928.

[6] Marín-Bustamante, M.Q., Chanona-Pérez, J.J., GüemesVera, N., Arzate-Vázquez, I., Perea-Flores, M.J., Mendoza-Pérez, J. A., Calderón-Domínguez, G. y Casarez-Santiago, R.G. (2018). Evaluation of physical, chemical, microstructural and micromechanical properties of nopal spines (Opuntia ficus-indica). Industrial Crops \& Producsts, 123, 707-718.

[7] A.O.A.C. (1995). Official Methods of Analysis (16 edición ed.). Washington D.C. USA: Association of Official Analytical Chemist.

[8] Ondo, S.E., Ryu, G.H. (2013). Physicochemical and antioxidant properties of extruded corn meal with natural cocoa powder. Food Science and Biotechnology, 22, 167175.

[9] Brand-Williams, Cuvelier, M.E., y Berset, C.L. (1995). Use of a free radical method to evaluate antioxidant activity. LWT-Food Science and Technology, 28 (1), 25-30.

[10] Benzie, I.F., y Strain, J.J. (1996). The Ferric Reducing Ability of Plasma (FRAP) as a Measure of "Antioxidant Power": The FRAP Assay. Analytical Biochemistry, 239 (1), 70-76.

[11] Siddhuraju, P., y Becker, K. (2007). The antioxidant and free radical scavenging activities of processed cowpea (Vigna unguiculata (L.) Walp.) seed extracts. Food Chemistry, 101 (1), 10-19. 